\title{
Strategies of Human Resource Management in Universities in Ebonyi State, Nigeria
}

\author{
Paul Nwakpa \\ Department of Educational Foundations \\ Faculty of Education, Ebonyi State University \\ Abakaliki, Nigeria \\ Email: bropaulnwaoo [AT] gmail.com
}

\begin{abstract}
This paper examined the strategies of Human Resources Management (HRM) in Tertiary institutions in Ebonyi State. Five (5) null hypotheses were formulated to guide the study, while a population of 570 academic staff of ranks of senior lecturers and above which represented (100\%) of the population as respondents. Z-test was used to test the null hypotheses and results indicated that all the null hypotheses were not rejected. From the findings, the following among others were recommended; HRM strategies should he harmonized in both state and federal universities adequate accommodation, teaching materials and conducive organizational climates be provided for staff motivation; all capacity building programmes for staff should be re-invigorated through adequate funding and universities should liaise with international donor agencies/countries to promote staff development through scholarship awards, exchange programmes, provision of research grants and fellowship programmes.
\end{abstract}

Keywords--- human resources, strategy, management, university etc

\section{INTRODUCTION}

A major component of the functions of an organization is management of human resource. The increasing popularity of the human resource management in Nigeria is a recent development which according to (9) Inyang (2008) can conveniently be dated to the last two decades. For example, the major reorganization of the Nigerian civil service in 1988, which led to the enactment of the Civil Service Reforms Decree No. 33 of 1988 (abrogated in 1995) recognized the strategic role of the human resource function and for the first time, created a separate directorate of personnel to handle this responsibility. This watershed development stimulated more interest in human resource management practices in organizations. Corporate executives in most public and private sector organizations often regarded material and financial resources as the most important assets. They later realized the significant role of human resource and that it is indeed, the very necessary and essential resource that energizes all other material and financial resources as for the achievement of organizational goals/objectives. Technically speaking, according to ${ }^{(14)}$ Peretomode (2005), without the personnel, no organization can be regarded as a human or social organization nor can their aims and objectives be achieved. For it is the personnel that plans, organizes, co-ordinates, budgets, supervises, monitors and evaluates all aspects of an organization. Sustainable progress can only be attained in organizations where skilled and unskilled personnel have been recruited, trained and motivated to perform their assigned tasks and functions.

There may be need for re-training and/or development when through job analysis and evaluation, it is discovered that the acquired skills, have become obsolete or when new ideas and technologies are needed to meet set standards. Human resource is therefore the most critical of all the resources required for the production of goods and services, hence the key for rapid economic development and efficient service delivery. Without adequate skilled, properly motivated workforce, operating with a sound human resource management programme, development will not be possible. ${ }^{(11)}$ Mathis \& Mathis (1982:6) note that:
"the successful management of human resources is one of the keys (of the effective cooperation of an organization. Managers in both the private and public sectors must tap the talent of their human resource if they are to be successful, if the organizations are lo accomplish their objectives"

According to ${ }^{(2)}$ Adeyeye (2009), the reason behind the establishment of University education in Nigeria is to co-ordinate and enhances the development and utilization of manpower in Nigeria. Admittedly, HRM practices are critical to the realization of this objective. As a result, universities should attract, develop and maintain an energetic workforce to support their strategies and achieve their goals. High commitment theories suggest a link between certain HRM practices and improved organizational performances. Prior studies according to ${ }^{(1)}$ Adeyeye (2008) have discovered that firms that employ comprehensive employee recruitment and selection procedures, extensive employee participation and training, experienced enhanced corporate financial performance. Positive relationship has equally been established between 
strategic HRM practices and productivity, turnover and firm performance. Past empirical research shows that there exists a bundle of HRM practices that can influence the performance of the firm ${ }^{(8)}$ (Huselid, 1997).

Human resource management has been given many definitions. Bateman \& Zeithami in Amalaha, O.O. (2004), regarded HRM as the formal systems for the management of people within the organization. Many concepts implied in this definition include for example, managing employees, training and development, staff motivation, enhanced employee commitment and quality performance. ${ }^{(5)}$ Armstrong (2004) considered HRM as a strategic and Coherent approach to the management of organizations most valued assets: the people working there who individually and collectively contribute to the achievement of its objectives. Similarly, ${ }^{9}$ Inyang (2008) defined FIRM as a set of organization - wide and people oriented functions or activities deliberately designed to influence employees' effectiveness in the organization. It is the organization's activities which are directed at attracting, developing and maintaining an effective workforce. ${ }^{(10)}$ Jackson $\&$ Schuler (1995) regarded HRM as an umbrella term that encompasses a system that attracts, develops, motivates and retains employees who ensure the effectiveness and survival of the organization and its members. Human resource management is both a field of study and practice. It focuses on the whole process of planning, funding, building, coordinating, utilizing workforce and handing the formal systems for the management of people within the organization until their retirement. According to Hall \& Goodale in Williams, C.R. \& Livingstone, L.P. (2003), HRM is the process of bringing people organizations together so that the goals of each other are met. Mathis \& Mathis considered HRM as the effective utilization of human resource in organization the management of people related-activities. ${ }^{(6)}$ Castetter (I984) observed that a premise of personnel administration is that the end result of education process determined to a large extent by the effectiveness of the school personnel. ${ }^{(19)}$ Storey (1989:4) classified the major focus of HRM as;

i) It seeks to bring together and develop into an effective organization of inner women who make up the enterprise, enabling each of them to contribute: quota to the success of the system both as individuals or work groups:

ii) It seeks to provide fair terms and conditions of employment and conditions for employees;

iii) It is concerned with creating, maintaining, stimulating and unifying energies of workers towards effective realization of their pre-determined goals / objectives.

iv) HRM has the capacity to provide adequate remuneration and reward that will motivate staff to stay and work productively in organizations,

From the discussion so far, HRM can conveniently be summarized as part of management that deals with people at work with regards to:

a) Utilization: recruitment, selection and training;

b) Motivation: job design, fringe benefits, remuneration, negotiation and justice;

c) Protection: work conditions, job-security, welfare services. Health and safety at work and implementation of appropriate organizational policies and programmes.

Most recent studies support the view that HRM can impact on organizational performance and lead to sustained competitive advantage. The concept of HRM as a source of competitive advantage implies that people have competencies, experiences and knowledge that add economic values to organizations. Organizations therefore have obvious justifications to develop and maintain effective and robust human resource management practices.

\section{THEORETICAL FRAMEWORK}

The theoretical framework for this study is derived from the Theory of Strategic Human Resources Management put forward by ${ }^{(19)}$ Storey (1989). The theory states that the fundamental aim of strategic HRM is to generate strategic capacity, ensuring that an organization has the skilled, committed and well-motivated employees it needs to achieve sustained competitive advantage. Its objective is to provide a sense of direction in an often turbulent environment so that the business needs of the organization, individuals and the collective needs of its employees can be met by the development and implementation of coherent and practical HR policies and programmes. It is an approach that involves the plans and intentions of organizations towards employment relationship, recruitment, training, development, performance management, reward and employee relations strategies, policies and practice. Strategic HRM addresses the extent to which HR strategy takes into account the interests of all stakeholders in the organization, employees in genera! as well as owners and management. Strategic HRM involves both 'soft strategic HRM' and 'hard strategic HRM'. 'Soft strategic HRM' places greater emphasis on job-security of staff, continuous development, communication, participative decision-making, quality work life and work-life balance, whereas 'Hard strategic HRM' emphasizes on what is to be obtained by proper human resource investment by organizations. An ideal strategic HRM however, attempts to achieve a proper balance between the hard and soft elements.

\section{STATEMENT OF PROBLEM}

The strategies of Human Resource Management in universities in Ebonyi state appears to have become most appalling. There appears to be an alarming and unmitigated decay in facilities for teaching and research, lack of current library material, inadequate manpower as a result of brain drain, poor infrastructure and inadequate funding. These may have 
given rise to low productivity, poor quality of graduates, anti- intellectualism, inadequate staff motivation and lack of systematic staff training and development programmes. The researcher is bothered about the effects of these constraints on staff morale. The study is concerned about what has to be done to fill the missing gaps in HRM strategies in universities in Ebonyi State in the areas of (i) staff motivation (ii) staff training and development programme and (iii) HRM benefits and challenges.

\section{RESEARCH HYPOTHESES}

The following five null hypotheses guided the study.

HO1: There is no significant difference between the mean ratings of academic staff of state and federal universities on the strategies adopted in HRM in Ebonyi State.

HO2: There is no significant difference between the mean ratings of academic staff of state and federal universities on the motivational variables available for HRM practices.

H03: There is no significant difference between the mean ratings of academic staff of state and federal universities on their participation in HRM training and development programmes in Ebonyi State.

H04: There is no significant difference between the mean ratings of academic staff of state and federal universities on the benefits of HRM in Ebonyi State.

H05: There is no significant difference between the mean ratings of academic staff of state and federal universities on the HRM challenges in Ebonyi State.

\section{METHODOLOGY}

The research design is a descriptive survey. Questionnaires were used to determine the strategies adopted, the benefits and challenges of human resources management in universities in Ebonyi State. The population for the study consisted two universities with 570 academic staff of the rank of senior lecturers and above. The total number of lecturers in each of the two universities was obtained from the various institutions' administration. A total of 570 lecturers of the rank of senior lecturers to professors, making a total of $100 \%$ of the population were used for the study. The instrument used for the study is a questionnaire titled "Human Resources Management Inventory" (HRMI), patterned after the modified Likerts Four Point Scale of Strongly Agree (SA), Agree (A), Disagree (D), and Strongly Disagree (SD) with weighted values of 4,3,2 and 1 respectively. The mean value of 2.50 was derived from the average of the weighted values. The instrument was face and content validated by close scrutiny by experts in the Departments of Educational Foundations Ebonyi State University, Abakaliki. The test-retest method was adopted to ascertain the reliability and consistency of the instrument. The correlation analysis of Pearson Product Moment Correlation Coefficient which produced a coefficient reliability of 0.86 .

The instrument was administered by the researcher. Out of five hundred and seventy questionnaires administered, five hundred and twenty were retrieved. Analysis of data was directed towards testing the five null hypotheses formulated for the study. Z-test was used to test the hypotheses at 0.05 level $(\mathrm{P}<0.05)$ of significance.

\section{RESULTS}

HO1 There is no significant difference between the mean ratings of academic staff of federal and state universities on the strategies adopted in managing human resource in Universities in Ebonyi State,

Table 1: Z-Test Analysis of Differences between the Mean Ratings of Academic Staff of Federal and State Universities on the Strategies Adopted in Managing Human Resources

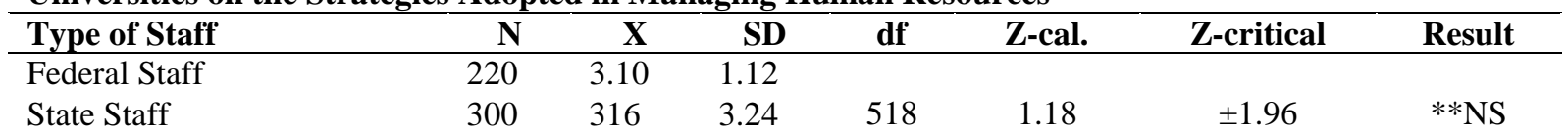

$* * \mathrm{NS}=$ Not significant at $\mathrm{P}<.05: * \mathrm{~S}=$ Significant.

Table I shows that at 0.5 level of significance and 518 degree of freedom, the Z-cal was 1.18 and $\mathrm{z}$-crit. 1.96. Since the zcal 1,18 is lower than Z-crit. \pm 1.96 , the null hypothesis was not rejected. There is therefore no significant difference between the mean ratings of academic staff of federal and state universities on HRM strategies adopted.

$\mathrm{HO}_{2}$ : There is no significant difference between the mean ratings of academic staff of federal and state Universities on the availability of HRM motivational variables in Ebonyi State. 
Table 2: Z-Test Analysis of Differences between the Mean Ratings of Academic Staff of Federal and State Universities on the Availability of HRM Motivational Variables

\begin{tabular}{lrrrrrrr}
\hline Type of Staff & $\mathbf{N}$ & $\mathbf{X}$ & SD & df & Z-cal. & Z-critical & Result \\
\hline Federal Staff & 220 & 3.10 & 1.12 & & & & \\
State Staff & 300 & 316 & 0.64 & 518 & 1.42 & \pm 1.96 & $* *$ NS
\end{tabular}

$* * \mathrm{NS}=$ Not significant at $\mathrm{P}<.05: * \mathrm{~S}=$ Significant.

Table 2 Indicates that the mean values of the federal staff (3.14) on all items measuring availability of motivational variables for HRM practices in tertiary institutions does not significantly differ from those of their state (2.45) counterparts. And since the value of cal-z (1.42) is less than that of crit-z $( \pm 1.96)$ at .05 levels of significance and 518 degree of freedom, the null hypothesis was not rejected. There is therefore no significant difference between the mean ratings of staff of federal and state Universities on the availability of motivational variables for HRM practices in Ebonyi State.

H03: There is no significant difference between the mean ratings of the academic staff of federal and state universities on their participation in HRM training and development programmes in Ebonyi State.

Table 3: Z-Test Analysis of Differences between the Mean Ratings of Academic Staff of Federal and State Universities Participation in HRM Training and Development Programmes in Ebonyi State

\begin{tabular}{lrrrrrrr}
\hline Type of Staff & $\mathbf{N}$ & $\mathbf{X}$ & SD & df & Z-cal. & Z-critical & Result \\
\hline Federal Staff & 220 & 3.10 & 0.94 & & & & \\
State Staff & 300 & 316 & 1.24 & 518 & 1.11 & \pm 1.96 & $* *$ NS
\end{tabular}

$* * \mathrm{NS}=$ Not significant at $\mathrm{P}<.05: * \mathrm{~S}=$ Significant

Table 3 indicates that the mean values of staff participation in human resources management training and development programmes in tertiary institutions in Rivers State are not different from each other. Furthermore, since z-cal (1.11) is less than z-critical $( \pm 1.96)$ at the degree of freedom (df) of 518 at .05 level of significance, therefore the hypothesis was not rejected. There is therefore no significant difference between the mean ratings of academic staff of state and federal Universities in their participation in training and development programmes in Ebonyi State.

H04: There is no significant difference between the mean ratings of academic staff of federal and state Universities on the benefits of HRM in Ebonyi State.

Table 4: Z-Test Analysis of Differences between the Mean Ratings of Academic Staff of Federal and State Universities on the I1RM Benefits in Ebonyi State

\begin{tabular}{lrrrrrrr}
\hline Type of Staff & $\mathbf{N}$ & $\mathbf{X}$ & SD & df & Z-cal. & Z-critical & Result \\
\hline Federal Staff & 220 & 2.05 & 1.44 & & & & \\
State Staff & 300 & 2.42 & 0.92 & 518 & 1.22 & \pm 1.96 & $* * N S$
\end{tabular}

$* * \mathrm{NS} * * \mathrm{NS}=$ Not significant at $\mathrm{P}<.05: * \mathrm{~S}=$ Significant

Table 4 indicates that the mean values of the benefits of HRM in both federal and state Universities in Ebonyi State do not differ significantly. And since the value of $\mathrm{z}$-cal (1.22) is less than the value of critical $\mathrm{z}$ at $( \pm 1.96)$ at .05 level of significance and 518 degree of freedom, the null hypothesis was not rejected. The result is that there is no significant difference between the mean ratings of academic staff of federal and state Universities on the benefits of HRM in Ebonyi State.

HO5: There is no significant difference between the mean ratings of academic staff of federal and stale Universities on the challenges of HRM in Ebonyi State.

Table 5: Z-Test Analysis of Differences between the Mean Ratings of Federal and State Universities on the HRM Challenges in Ebonyi State

\begin{tabular}{lrrrrrrr}
\hline Type of Staff & $\mathbf{N}$ & $\mathbf{X}$ & SD & df & Z-cal. & Z-critical & Result \\
\hline Federal Staff & 220 & 3.10 & 1.14 & & & & \\
State Staff & 300 & 3.20 & 0.84 & 518 & 1.12 & \pm 1.96 & $* * \mathrm{NS}$ \\
& & & & & & &
\end{tabular}


Table 5 suggests that there is no significant difference in the mean values of the challenges of HRM in Universities in Ebonyi State and since the value of $\mathrm{z}$-critical $( \pm 1.96)$ is greater than that of $\mathrm{z}$-cal $(1.12)$ at .05 level of significance and 518 degree of freedom, the null hypothesis was not rejected.

\section{DISCUSSION OF FINDINGS}

The data in table 1 indicated a no significant difference between the mean ratings of academic staff of federal and state Universities on the strategies of human resource management adopted. But Merlie and Thames cited in ${ }^{(13)}$ Onyike (2004) demonstrated that HRM practices were executed through different strategies. Higher institutions are required to put in place strategies that will identify key areas of training and development for improvement of competitiveness. The key choice for tertiary institutions corporate strategies include the balance between teaching, research, consultancy, public service (community development) and academic disciplines which it operates. Linkages and collaborations between and among tertiary institutions are strategies that will help them achieve their statutory responsibilities. This could be actualized through conferences, workshops, seminars, public lecturers, fellowship programmes and membership of academic unions and professional examinations. ${ }^{(12)}$ Olajuwon (2010) agreed when he noted that inter-university linkages and co-operation will contribute to national development in the area of research, joint co-operation, mutual respect and understanding.

Assessment of the data in table 2 suggested that there is no significant-difference in the mean ratings of academic staff on motivational variables for HRM practices. Motivation is a very important factor in HRM practices. According to ${ }^{(4)}$ Amalaha (2004) motivation has a positive influence on the achievement of organizational goals. ${ }^{(20)}$ Trevor (2003) agreed when he confirmed that motivation positively influence employees performance. ${ }^{(21)}$ William \& Livingstone (2003) submitted that negative performance turn-over was stronger in organizations using performance countering reward system. Findings from previous studies indicated that while sabbaticals, regular promotions and in-service training programmes are the available motivational variables in both state and federal tertiary institutions, accommodation, adequate teaching materials and conducive organizational climates are not. As a result, ${ }^{(16)}$ Sailor $\&$ Trevor (2003) suggested that organizations provide employees with enriched basket of fringe benefits, refined jobs so that they become meaningful, pay equal or higher salaries than their competitors, sponsor special training or higher education programmes for them to be able to retain efficient and productive workforce.

Testing null hypothesis $\left(\mathrm{HO}_{3}\right)$ in table 3 suggested that there is no significant difference in the mean ratings of academic staff participation in HRM development programmes. In Nigeria Universities, development programmes for academic staff involves carrying out researches and presenting same in conferences, workshops and seminars and publishing them in recognized journals. Other HRM development programmes such as study leave with full sponsorship, sponsored oversea conference, training, workshops and seminars according to ${ }^{(7)}$ Ejiogu (1985) have become extinct. Fasanmi in ${ }^{(3)}$ Aliju (1997) \& Amalaha (2004) confirmed that such privileges are no longer enjoyed by staff of tertiary institutions in Nigeria. But academic staff is one of the most important resources of a college or university. Just as materials resources are given special care and attention in order to retain and maintain their values, so should talents, interests and skills be systematically cultivated. Faculty development should be considered an important tool for total institutional renewal,

Testing null hypothesis $\left(\mathrm{HO}_{4}\right)$ in table 4 suggested that there is no significant difference between the mean ratings of academic staff in federal and state Universities on the benefits of HRM in tertiary institutions in Ebonyi State, This findings is in agreement with the research findings of William \& Loader in ${ }^{(15)}$ Robert-Okah (2011) that HRM contributed greatly towards the improvement of staff skills, knowledge and teaching competence. HRM does not only improve the quality of certificates, diplomas and degrees awarded but also ensures that the quality of teaching and research are of international standards. HRM equally assists employees to gain new capabilities, evolve a skill-based pay, new ways of facilitating knowledge exchange and mutual learning within an organization. ${ }^{(7)}$ Ejiogu (I9S5) concurred when he submitted that HRM aims primarily to systematically identify talents, improve skills, widen experiences and assist staff to grow in ability to accept greater responsibility.

The data in table 5 arising from testing null hypothesis $\left(\mathrm{H}_{5}\right)$ suggested a no significant difference among all categories of senior academic staff of state and federal Universities in Ebonyi State on HRM challenges. This is in agreement with the findings of ${ }^{(17)}$ Saint, Hartnett \& Strassner (2003) which discovered that declining funding, rising workloads associated with deteriorating staff/student ratio and dwindling research activities are prevalent in Nigeria tertiary institutions. Equally unsettling is the challenge of 'brain drain' on the adequacy of manpower on HRM in tertiary institutions. According to ${ }^{(18)}$ Sodeinde (2006), 'brain drain' does not only influence the individuals involved but institutions and countries also bear the brunt of the loss. Implications of 'brain drain' can be devastating for a developing country such as Nigeria. Efforts to expand enrolments and improve educational quality are severely constrained by the growing shortages of qualified academic staff. 


\section{CONCLUSION}

The study discovered that poor HRM strategies are adopted and this may have resulted from the problem of underfunding, inadequately trained HRM practitioners and problem of 'brain drain'. The study equally ably demonstrated numerous benefits/contributions of HRM such as improvement of staff skills, knowledge and teaching competence. In addition HRM equally improves the quality of certificates, diplomas and degrees awarded. The study was able to discover that there is no significant difference in the challenges affecting HRM practices in Universities in Ebonyi State and that such challenges include declining funding, rising workload associated with deteriorating staff/student ratio and declining research activities. The implications of the 'brain drain' phenomenon for a developing country such as Nigeria were equally highlighted.

\section{RECOMMENDATIONS}

1) A special mechanism should be established to harmonize all the HRM strategies that are beneficial to tertiary institutions.

2) Accommodation, proper funding, adequate teaching materials and conducive organizational climates should be provided to motivate staff.

3) Such HRM development programmes as orientation, study - leave with pay, sponsored seminars, workshops, conferences, overseas training and other capacity building programmes should be re-invigorated through adequate funding.

4) Regular capacity building programmes for HRM practitioners will retool them to sustain and improve in the benefits of HRM practice.

5) Universities should liaise with international donor agencies/countries to promote staff development through scholarship awards, provision of research grants and fellowship programmes.

\section{REFERENCES}

1. Adeyeye, F. (2008). Globalization and the challenges of human resource management in Africa, proceedings of the 9" annual international conference of the International Academy of Africa Business and Development in S. Simon (ed) held at the University of Florida, Gainesville, USA 9:487-498.

2. Adeyeye, J.O. (2009)- An evaluation of human resource management (HRM) practices in Nigerian Universities: The impact of size in E. Armstrong (ed.) Pakistan Journal of social sciences 5(6) 534-544.

3. Aliju, Y.A. (1997). Manuel of University management. Abuja: Espec printing.

4. Amalaha, O.O. (2004). Human resource utilization in tertiary institutions in Abia State. Unpublished Ph.D Thesis; Department of Educational Management, Faculty of Education, University of Port Harcourt, Choba, PH.

5. Armstrong, M. (2004). , 4 handbook of human resource management practice. (9 ' edn). New Delhi: Kogan Page India.

6. Castetter, W.B. (1984). The personnel functions in educational administration. New York: Macmillan Publisher Coy.

7. Ejiogu, A.M. (1985). Theories of job satisfaction and job performance: An oreniew and critique. Lagos: Joja Education Research and publishers.

8. Huselid, M.J. (1997). Technical strategic human resource management effectiveness as determinants of firm performance. Academic Manager J. Florida, USA 40(3) 178-188.

9. lyang, B.J. (2008). Bridging the existing gap between human resource management function (HRMF) and enterprise management (E.M) in Nigeria in E, Armsti'ong (ed.) Pakistan Journal of social sciences 5(6) 534544.

10. Jackson, S.E \& Schuler, R.S. (1995). Understanding human resource management in the context of organizations and their environments. Annual Review Psychology Retrieved from www.questia.com (I--23), 
11. Mathis, R.L \& Matin's, J.II (1982). Personnel: Contemporary perspectives and. applications. (3 ${ }^{\text {rd }}$ edition). St. Paul, M.M. West Publishers.

12. Olajuwon, O.T. (2010). Education in Nigeria: A futuristic perspective retrieved from http.Ywww. The daily star net/magazine html.

13. Onyike, V,C. (2004). Human resource development of academic staff in Nigerian Universities in the South-East Geo-political zone, Nigeria. Unpublished Ph.D Thesis; Department of Educational Management, Faculty of Education, University of Port Harcourt, Choba, PH.

14. Peretomode, V.E. (2005). Human resources management, Lagos: Onosomegbowho Ogbinaka Publishers,

15. Roberl-Okah, 1- (2011). Managing human resources in tertiary institutions in Rivers State. Unpublished Ph.D Thesis, Department of Educational Management, Faculty of Education, University of Port Harcourt, Choba, PH.

16. Sailors, J.F \& Trcvor, CO. (2006). Reduce the cost of employee turnover. Journal of Compensation and benefits. 9(5), 32-38.

17. Saint, W., Hartnett, A.A \& Strassner, E. (2003). Higher education in Nigeria: A status report. World Education News and Reviews.

18. Sodeinde, O.O. (2007). Globah'/ation, migration and brain drain: The experience of Olabisi Onabanjo University Nigeria in L. Moluka (ed.) African in the New Millennium, Africa Institute of South Africa, 86-95.

19. Storey, J. (1989). New perspectives on human resources management. London: Routledge.

20. Trevor, CO. (2003). Voluntary turn-over and job performance: Curvilinearity and the moderating influences of salary growth and promotions. Journal of Applied Psychology 82(1), 44-61.

21. Williams, C.R. \& Livingstone, L.P. (2003). Another look at the relationship between performance and voluntary turnover- Academy of Management Journal, 37(2) 269-298. 